\title{
Toprak Reformu Kapsamında Toplulaştırma: Balıkesir-Gönen İlçesindeki Bir Uygulamanın Değerlendirilmesi
}

\author{
Kemal Yildiz ${ }^{1}$ \\ ORCID: 0000-0001-6685-3805
}

\author{
Halil İhsan Karalar ${ }^{2}$ \\ ORCID: 0000-0003-3147-4105
}

Öz

Toprak ile ilgili meseleler ilk çağlardan bugüne hep insanliğın gündeminde olan bir konudur. Tarımsal faaliyetlerin gerçekleştirildiği topră̆ın ne şekilde kullanılması gerektiği doğrudan verimlilikle ilişkili bir konu olduğundan, bu alanda devamlı reformlar yapılması kaçınılmaz olmuştur. Dünya nüfusunun gittikçe artması ve sintrl olan tarımsal alanların mülkiyet yoluyla bölünmesi, toprak reformlarmm en önemlilerinden olan toplulaştırma düzenlemelerini kaçınılmaz kılmıştır. Türkiye'de işletilen tarımsal alanlarına sahip kişilerin ancak \% 8 gibi bir kısmı bu topraklarda üretim gerçekleştirmektedir. AB Ülkeleri tarımsal işletme büyüklükleri Türkiye'dekilerin iki katı, ABD'kiler ise üç katıdır. Türkiye'deki tarımsal işletmelerin çoğalıp gelişmesinin önündeki en büyük engellerden birisi, toprakların küçük ve çok parçalı yapıya sahip olmasıdır. Bu çalışmada öncelikle toprak reformu ve toplulaştırma konuları ve tarihçeleri, Türkiye'de toprak reformu ve çalışmaları ve hukuki düzenlemeler, toprak reformu çerçevesinde Türkiye'de arazi toplulaştırması ele alınmıştır. Daha sonra sahalveri çalışması yapılmıştır. Sonuçta bu konularda ciddi problemlerin olduğu tespit edilmiştir. Problemlerin giderilmesi adına miras hukukunun güncellenmesi ile üretimi önceleyen bir Tarım Kanununun çıkarılması elzemdir.

Anahtar Kelimeler: Toprak reformu, toplulaştırma, Gönen, tarımsal üretim, tarımsal mevzuat.

\footnotetext{
${ }^{1}$ Doç. Dr., Bandırma Onyedi Eylül Üniversitesi, E-mail: kyildiz@bandirma.edu.tr

${ }^{2}$ Tapu Müdürü, Gönen Tapu Müdürlüğü, E-mail: hihsankaralar@gmail.com id ealkent (c) Kent Araştırmaları Dergisi (Journal of Urban Studies) 


\title{
Land consolidation within the Scope of Land Reform: Evaluation of an Application in Balıkesir-Gönen District
}

\author{
Kemal Y1ldiz 3 \\ ORCID: 0000-0003-3639-2512
}

\author{
Halil İhsan Karalar 4 \\ ORCID: 0000-0003-3147-4105
}

\begin{abstract}
Land-related issues have been on the agenda of mankind since the early ages. How to use the soil where agricultural activities are carried out is directly related to productivity. Thus, continuous reforms in this area have been inevitable. Increasing world population and division of limited agricultural lands through property have made inevitable consolidation arrangements that one of the most important land reforms. Only $8 \%$ of people with part-run agricultural area in Turkey is carrying out production on these lands. Agribusiness sizes of EU countries are double than Turkey's. In USA has triple. One of the biggest obstacles in the proliferation and development of agricultural enterprises is such small and multi-part structure of soils. Firstly, in this study, land reform and consolidation issues and histories, land reform studies and legal arrangements in Turkey, within the framework of land reform, land consolidation is in Turkey were discussed. Then, field / data study was conducted. As a result, it has been determined that there are serious problems in these matters. In order to solve the problems, it is essential to enact an Agriculture Law that prioritizes production and it is essential to update the inheritance law.
\end{abstract}

Keywords Land reform, land consolidation, Gonen, agricultural production, agricultural legislation.

\footnotetext{
${ }^{3}$ Assoc. Dr., Bandırma Onyedi Eylül University, E-mail: kyildiz@bandirma.edu.tr

${ }^{4}$ Land Registry Office Director, Gönen Land Registry Office, E-mail: hihsankaralar@gmail.com

idealkent @ C Kent Araştırmaları Dergisi (Journal of Urban Studies)

http://idealkentdergisi.com

Geliş Tarihi Received Date: 10.08.2020 Kabul Tarihi Accepted Date: 14.04.2021
} 


\section{Giriş}

En gelişmiş tarım faaliyetinden en ilkel tarım faaliyetine kadar tüm tarımsal faaliyetlerin olmazsa olmazı topraktır. Bir üretim unsuru olarak toprağ 1 diğer üretim faktörlerinden ayıran yönü ise yeryüzündeki büyüklügünün sabit olmasıdır. Sınırlı bir miktarda var olan bu toprağa sahip olarak kullanma çabalarının ilkel insanların toplayıcılık ve avcılıktan vazgeçerek, hayvan ve toprağın ıslahı ile tarımsal faaliyetlere başlamalarına tarihlendiği görülmektedir. Bu sürecin yani göçebe toplumdan yerleşik topluma geçişin tarım yapılan toprak miktarlarının ve sahipliğinin dağılımındaki eşitsizliğinin de başlangıcı olduğunu düşünmek mümkündür. Asırlar boyu süregelen bu eşitsizliğin ortadan kaldırılmasina yönelik olarak tarihte pek çok girişimin mevcut olduğu, çözüm arayışlarının günümüze kadar geldiği anlaşılmaktadır.

Toprak reformu genel olarak; tarım arazilerinin dağılımının mümkün olduğunca adilane olması, toprağın işleyenin mülkiyetinde yer alması, etkin ve verimli tarım yapılması amacıyla tarım arazilerinin bütünlüğünün korunması, tarım üretiminde çalışan topraksız ya da az toprak sahibi kişilerin toprak sahibi olması gibi prensipleri barındırır. Bu prensipler; devlet arazilerinin topraksız ya da az topraklı kişilere belirli kriterler dâhilinde dağıtılması, kişi ya da işletmelerin verimli tarım yapmasına yönelik araç ve gereçlerle donatılmaları ile tarımsal faaliyetlerin yapıldığı alanların toplulaştırılması suretiyle etkin ve verimli kullanımın sağlanması gibi bir takım faaliyetler ile hayata geçebilir.

$\mathrm{Bu}$ çalışmada toprak reformunun tarihsel gelişimi ile bu süreçteki toprak reformu çalışmaları irdelendikten sonra, ülkemizdeki toprak reformu çalışmaları hakkında bilgi verilecektir. Daha sonra toprak reformu çalışmalarının bir adımını teşkil eden arazi toplulaştırması uygulamaları değerlendirilip, Balıkesir ili Gönen ilçesi özelinde bir uygulama irdelenerek, sonuç bölümünde konuya ilişkin önerilere yer verilecektir.

Bugüne kadar yapılan kavramsallaştırma ve uygulamalara bakıld1ğında toprak reformu, genellikle daha büyük topraklarda üretim yapabilme ile modern ve verimli toprak işleme yöntemlerinin kullanılması şeklinde tanımlanabilmektedir. Toprak reformu ile ilgili ilk çalışmaların milattan önce 900'lü yıllara uzandığını bilinen bir gerçektir (Berki, 1970, s. 79; Pamak, 2011, s.129-131). O günden bugüne hemen hemen tüm toplumlarda toprak reformuna ilişkin düzenlemelerle karşılaşmak mümkündür. Türkiye'de ise Osmanlı Devleti'nin son döneminden başlayan 
ve bugün halen belirli bir kemâle erememiş düzenlemeler mevcuttur. Arazi toplulaştırması meselesi, toprak reformu konusunda en önemli ve problemli mesele olarak varlığını sürdürmektedir. Arazi toplulaştırmasının sağlayacağı sosyal ve ekonomik faydalar açık olmakla birlikte uygulama istenen etkinlik ve düzeyde değildir. Yapılan saha çalışmasında da toplulaştırma uygulamaları ve miras hukukundaki yetersizliklerden yakınılmıştır.

\section{Toprak Reformu Kavramı}

Toprak Reformu dar anlamda toprakta mülkiyetin yeterli toprağı olmayan küçük çiftçiler ile tarımda çalışıp toprağı olmayanlara yeniden dağıtımını ifade etmektedir. Günümüzde bu tanım daha da genişletilerek tüm tarımsal ekonominin değişimini öngören kapsamlı bir program olarak değerlendirilmektedir (Tekelioğlu, 2010, s.44). Benzer bir şekilde Toprak Reformu kavramı; 'tarımla ilgili tüm kurumların daha iyi duruma getirilmesi ve iyileştirme için alınacak önlemlerin tümünü ifade eder' şeklinde tanımlanmaktadır. Bunu sağlamak üzere devletin büyük tarım arazilerinin parçalanarak belirli ölçüler dâhilinde çiftçilere dağıtılması konusunda alacağı karar ve tedbirler de toprak reformu kavramı içerisinde değerlendirilebilir (İnci, 2010, s. 345). Yine Toprak Reformunun, belirli zümrelerin elinde toplanan tarım yapılabilir arazilerin devlet eliyle ve kanun gücüyle kamulaştırılarak ya da devletin mülkiyetinde bulunan hazine arazilerinin topraksız köylülere dağıtılması eylemi olarak da tanımlandığı görülmektedir (Kaya, 2015, s. 78).

\section{Toprak Reformunun Tarihine Kısa Bir Bakış}

Toprak Reformu konusunda tarihte kayda geçmiş ilk uygulamalara MÖ 800 yıllarında Likürg (MÖ 884-804) Kanunu ve MÖ 400 yıllarında Solon (MÖ 640-560) Kanunları ile rastlanılmaktadır. Antik Yunan şehirlerinde yaşayan siyasi, dini etkinliği olan zengin toprak sahipleri ile topraksız köleler ve özgür olmakla birlikte toprağın işlenmesinde çalışan ancak bundan elde edilen gelirden pay alamayan kişilerin taraf olduğu büyük ve kanlı olaylar neticesinde Likürg tarafından toprak dağıtım kanunlarının yapıldığı bilinmektedir. Solon Kanunlarının toprak reformunun yanında toplumun gelişimini sağlayacak pek çok reformu da kapsadığ görülmektedir. M.Ö. 100’lü yıllara kadar ‘Lex Cassia Agraria, İcinius, Elaminus, Sempronia, Thoria ve Sezar Kanunlarının Toprak reformu 
konusunda çıkarılan kanunlar olduğu anlaşılmaktadır. Ancak bu kanunlar çok uzun süreli olarak uygulamada kalmamış ve büyük toprak sahipleri ile yönetimi eline geçiren erk tarafından yürürlükleri sonlandırılmıştır (Berki, 1970, s. 79; Pamak, 2011, s. 129-131).

Avrupa'da Ortaçağda ortaya çıkan feodal yapıya bağlı olarak topraklar üzerinde krallıkların ve kilisenin mülkiyetinin yoğun olarak mevcut olduğu görülmektedir. Derebeylikler ve onlara bağlılıklarını ilan etmiş geniş toprak sahiplerinin yönetimindeki topraklarda üretim bu dönemde Serf olarak adlandırılan köylüler tarafından yapılmaktaydı (Kılıç ve Demirbilek, 2011, s. 183). Ortaçağ boyunca devam eden bu toprak rejiminin Fransız Devriminin yarattı̆ 1 atmosferde yeniden şekillendiğinin, feodal düzenin yıkılması ile birlikte yeni bir toprak reformunun başladığını söylemek mümkündür. Bu reform ile birlikte insanların serf olmaktan kurtulduğu, köylülerin toprak sahibi olmaya başladığı bir dönem yaşanmıştır. Başta Fransa olmak üzere İngiltere, İsveç ve Danimarka gibi ülkelerde 1800'lerin başında, Almanya, İtalya ve İspanya gibi ülkelerde 1800'lerin ortalarından itibaren toprakların yeniden dağıtıldığı görülmektedir (Türker, 2010, s. 42).

Rusya'da toprak reformunun ise 1861 yılında Rus köylüsünün serfliğinin kaldırılmasıyla başladığı anlaşılmaktadır. Serfliğin kaldırılması ile birlikte serflikten kurtulan çiftçilere ortalama 10 dekar civarında toprak verildiği, hazine arazilerinin de 49 yıl gibi uzun vadelerle topraksız çiftçilerin kullanımına verildiği görülmüştür (Güdül, 2017, s. 5). Ancak 1917 yaşanan Sovyet Devrimi ile ülkedeki özel mülkiyet sona erdirilerek toprak mülkiyeti kamu mülkiyetine dönüşmüştür. Doğu Avrupa'da Macaristan, Romanya ve Bulgaristan'daki reformlar da 19. Yüzyılın ortalarından itibaren başlamaktadır. Adaletsiz bir toprak dağılımına sahip bu ülkelerde de daha adil ve modern anlamdaki toprak reformları ancak 2 . Dünya Savaşı sonrasında başlayabilmiştir. Latin Amerika (Meksika örneği hariç, Meksika'daki Toprak reformu 1917 yılında yürürlüğe konulan Anayasa ile başlamaktadır), Güneydoğu Asya'da reformların 20. Yüzyılın ikinci yarısına tarihlendiği görülürken, Ortadoğu'da ise M1sır'da 1950'li yıllarda yapılan reformların etkisi ile toprak reformlarının yapılmaya başlandığı anlaşılmaktadır (Elias, 1998, s. 3). Dünyanın pek çok ülkesinde yapılan toprak reformlarının ayrıntıları ayrı bir çalı̧̧ma konusunu oluşturmaktadır. Çalışmanın bundan sonraki bölümünde Türkiye'deki toprak reformu çalışmaları konusunda bilgi verilecektir. 


\section{Türkiye'de Toprak Reformu Çalışmaları ve Hukuki Düzenlemeler}

Türkiye'de tarım reformunun tarihçesine öncelikle Osmanlı Devletinin son dönemindeki toprak mülkiyetinin yapısının irdelenmesi ile başlamanın daha doğru olacağı değerlendirilmektedir.

\section{9-1918 döneminde Osmanh Devleti'nde toprak mülkiyetinin genel görünümü}

Osmanlı Devleti'nde topraklar kullanım ve mülkiyet durumlarına göre üç grupta toplanmıştır. Öşrî topraklar Müslüman halkın mülkiyetinde olan ve öşür vergisi ödenen topraklar, haracî topraklar fethedilen ve devlet mülkiyetindeki topraklar, mirî topraklar ise kira karşılığı kullandırılan yani kiracılarının kullanımında olan topraklardır. Osmanlı ekonomisinin temelini tarımsal faaliyetler oluşturmuştur. Tarım yapılan arazinin mülkiyetinin devlette olması esası ile birlikte tarımsal amaçlı kullanımlar için tespit edilen en uygun toprak büyüklüklerinin korunması ve bozulmaması için gerekli tedbirlerin alındı̆̆ı görülmektedir (Güneş ve Sarı, 2005, s. 73-74). Miri arazilerin hak sahiplerine dağıtılması ve sonrasında büyük çiftlikleri ele geçirmek suretiyle zenginleşen ayân ve reaya ile devlet arasında önemli problemlerin doğduğu, merkezi otoritenin bozulmasıyla birlikte tarımsal alanların mülkiyet yapılarında hızlı bir şekilde adaletsiz bir dağılımın oluşmaya başladı̆̆ı anlaşılmaktadır. Yaşanan tüm bu olumsuzlukların neticesinde çözüm üretmek üzere 1858 yılında Arazi Kanunu (Kanunnâme-i Arâzî) yürürlüğe girmiştir. Toprağın kullanım hakkının bireylere verilmesi öngörülmüş olmakla birlikte kendisine toprak verilenlerin bizzat tarım yapma zorunluluğu olmayıp, modern anlamda arazi yeter büyüklüğüne göre toprak verilmesi gibi bir ölçünün de olmadı̆̆ı anlaşılmaktadır. Bu kanun ile arazi beş kategoriye ayrılmaktadır. Tarım arazilerinin tarım dışı amaçlarla kullanımın önüne geçmeye yönelik tedbirler içermektedir. Toprağın kullanım hakkının bedel ile ya da miras yolu ile devrine ilişkin hükümler ihtiva etmektedir. Toprağın belirli kişi ya da zümrelerin elinde toplanması ve tekel oluşmasını önlemek amacıyla tedbirler aldı̆̆ı ayrıca özel mülkiyete konu arazi için geçerli olan hukuki durumların devlet mülkiyetindeki arazi için geçerli olmayacağı hakkında hükümler yer almaktadır (Kenanoğlu, 2006, s. 111). Kullanıcılar arasındaki toprak dağılımındaki adaletsizliği ve devletin toprak üzerinde sarsılan otoritesinin yeniden inşasını amaçlayan kanunun bunları sağlamakta yetersiz kaldığı hatta adaletsizliğin artmasına dahi sebep olduğu konusundaki görüşün yaygın olduğu 
görülmektedir. 1912-1913 yıllarında yapılan tarım sayımında sayımı yapılan ailelerin \%1'ini büyük toprak sahibi aileler oluşturmakta olup, bu ailelerin topraklarının \%39'una sahip oldukları anlaşılmaktadır. Öte yandan sayılan ailelerin \%87'sini oluşturan küçük toprak sahibi ailelerin ise toprakların \%35'ine sahip olduğu görülmektedir. Yine aynı sayımda topraksız köylülerin toplam tarımsal nüfusun \%8'ini oluşturduğu anlaşlmaktadır. Cumhuriyetin kuruluşu döneminde devletin en temel sosyal politika sorunlarından birinin toprak dağılımındaki adaletsizlik, topraksızlık sorunu olduğu anlaşılmaktadır (Önal, 2010, s. 7-8).

23 Nisan 1920 tarihinde Ankara'da Büyük Millet Meclisinin açılması ile yeni bir kimliğe bürünen ülke 29 Ekim 1923 tarihinde Cumhuriyetin ilanı ile yeni bir yönetim biçimine geçmiştir. Cumhuriyetin ilanı ile birlikte ülke genelinde kapsamlı değişim hareketleri başlamıştır. Özel mülkiyete olanak sağlayan bir kısım yasal düzenlemelerin cumhuriyetin ilk yıllarında hayata geçtiği görülmektedir. Bunların ilkleri 1924 Anayasası, 1925 yılında kabul edilen Kadastro Kanunu ve 1926 yılında kabul edilen Medeni Kanundur. Yine 1925 yılında aşarın (Aşar(öşr) vergisi üretilen mahsulün \%12,5'i oranında vergi olarak devlete verilmesidir) kaldırılması toprağı işleyenler açısında önemli bir gelişmedir. Medeni Kanunun kabulü ile özel mülkiyete dayalı bir hukuk sistemine geçilerek o tarihe kadar arazilerin kullanıcısı olan kişilerin bu arazileri özel mülk olarak adlarına tapuya kaydettirmelerine olanak sağlanmıştır. 1929 yılında çıkarılan bir diğer kanun ile Osmanlı Devleti zamanında çeşitli ailelere verilmiş olan ve geniş arazilerde tasarruf hakkı sağlayan beratların yeni Medeni Kanun bağlamında taşınmazların özel mülk olarak tapuya kaydedilmesi için yeterli belge sayılmıştır. Bu sayede geniş topraklarda işletme hakkına sahip ailelerin bu toprakları adlarına özel mülk olarak tapuya kaydetmelerinin önü açılmıştır (İnci, 2010, s. 351).

Cumhuriyet döneminde toprak sorunları ile ilgili temel düzenlemelerin başlaması yönetimin toprak reformundan etkilenmeleri kesin olan büyük toprak sahiplerinin ki Kurtuluş Savaşı'nın kazanılmasında büyük destekleri olmuşlardır, bunların tepkilerini çekmemek konusundaki hassasiyeti nedeniyle 1933-1934'lü yıllara ulaşılması gerekmiştir (Korkut, 1984, s. 45). Gündeme getirilen ancak yasalaşma imkânı bulamayan çalışmalar yapılmakla birlikte köklü bir toprak reformunun önünde sürekli bir direnç ile karşılaşılması nedeniyle gerçekleştirilmesi sürekli geciktirilmiştir. 14/06/1934 tarihli Resmi Gazetede yayımlanarak yürürlüğe giren 2510 sayılı İskân Kanunu toprak ve mülkiyet konularında önemli 
değişiklikler içermektedir. Kanunun toprakların tek elde toplanmasının önüne geçmeyi, büyük arazi sahipleri ile kırsal kesimde oluşan ağayarıcı, maraba, ortakçı şeklindeki üretim ilişkilerini tasfiye etmeyi amaçladığı görülmektedir. Ancak uygulamanın yalnızca kâğıt üzerinde kald1ğ1 görülmüştür. 1935 yılında Atatürk'ün talimatıyla Zirai Islahat Kanunu çıkarılması konusunda çalışmalara başlanılmışsa da Atatürk'ün ölümü ile bu çalışmaların kanunlaşmasının mümkün olmadığı anlaşılmaktadır (Çamurcuoğlu, 2009, s. 171). ${ }^{5}$

Yine bu yıllarda toprak reformu ile birlikte değerlendirilmesi gereken ve eğitim alanında bir reform olmakla birlikte özellikle kırsalda yaşayanlara bilgi, görgü ve teknoloji eğitimi vermeyi amaçlayan Köy Eğitmeni Projesi olarak başlayan ve sonraki yıllarda kanun ile Köy Enstitüsü adını alan çalışmadan da bahsedilebilir. Bu projede askerliğini erbaş olarak yapmış gençler Muradiye Devlet Üretme Çiftliğinde modern tarım araçları ile tarım yapmak ve diğer konularda yetiştirilerek eğitimci olarak köylere gönderilir. Köylerde yaşayanların bu sayede modern üretim araçlarını ve yöntemlerini kullanarak tarım yapması aynı zamanda köylerin eğitim ihtiyacının karşılanması hedeflenmiştir.

Toprak reformu adına en önemli adımlardan biri 1945 yılında yürürlüğe giren 4753 sayılı 'Çiftçiyi Topraklandırma Kanunu'dur. Kanun teklifi 'Çiftçiye Toprak Dağıtılması ve Çiftçi Ocakları Kurulması Hakkındaki Kanun Tasarısı' olarak yapılmış, ancak Mecliste yaşanan çok çetin tartışmalar neticesinde son kısmı tasarıdan çıkarılarak kanunlaşmıştır. Kanunun amacı; hiç toprağı olmayan ya da yeterli miktarda tarımsal topra$\breve{g}_{1}$ bulunmayan çiftçilerin, bununla birlikte kanunda topraklandırılmaları gerekli kişiler olarak tanımladığı kişilerin geçimlerini sağlamak zorunda oldukları ile birlikte emeklerini değerlendirerek ekonomik olarak güçlenecekleri miktarda toprak sahibi yapmak olarak belirtilmiştir. Yeterli miktarda toprağı olmasına karşın gerekli donanımları ve sermayesi olmayan çiftçilere de kredi ve çeşitli demirbaşlar vermek suretiyle sürekli ve etkili tarım yapılmasını sağlamak olarak özetlenebilir. Kanunun 7. maddesinde geçerli bir mazereti olmaksızın 3 yıl süre ile topraklarını

\footnotetext{
${ }^{5}$ Dönemin Maarif Vekili (Milli Eğitim Bakanı) Hasan Alî Yücel, TBMM genel kurulunda yaptığı bir konuşmada "Biz köy enstitüsünü sadece içerisinde nazarî tedrisat yapılan bir müessese olarak almadık. İçerisinde ziraat sanatları, demircilik, basit marangozluk gibi amelî bir takım faaliyetler de bulunduğu için okul adı ile anmadık, enstitü diye isimlendirmeyi muvafik gördük." demek suretiyle kurumun amacını özetlemektedir. Hedefi halkın ekonomik, kültürel yaşama aktif olarak katılımını sağlamak olduğu anlaşılan bu reformun da pek çok reform gibi gerekli desteği görmemesi ve politik hesaplar sebebiyle sonlandığı görülmektedir (www.meb.gov.tr).
} 
işlemeyen çiftçilerin topraklarının topraksız çiftçilere dağıtılacağı, 8. Maddesinde ise dağıtımı yapılacak arazi hakkında bilgi verilmekteydi. Önemli bir ayrıntı ise 14. madde metnindeki "Gerçek kişilerle özel hukuk kişilerine ait araziden beş bin dönümü geçen parçaları" nın kamulaştırılacak olmasıdır. Bu kanun kapsamında yapılan topraklandırmalar neticesinde oluşan yeni maliklerin bu arazilerini 25 yıl süre ile elden ç1karamayacakları hükmü bulunmaktaydı. 1973 yılına kadar yürürlükte kalan kanunun 1950 yılında 5618 sayılı kanun ile kamulaştırma miktarlarına sınırlandırma getirilmiş, 1955 yılında yapılan değişiklik ile de yalnızca devletin hüküm ve tasarrufunda bulunan arazilerin dağıtılacağ hükmünü içeren bir hal alarak gerçek amacından uzaklaştırılmıştır (Çamurcuoğlu, 2009, s. 173-174, Güneş ve Sarı, 2005, s. 79-80).

Türkiye'de arazi toplulaştırma çalışmaları 1960 yılında yürürlüğe giren 7457 sayılı "Ziraat Vekâleti Toprak Muhafaza ve Zirai Sulama İşleri Umum Müdürlügü teşkilat ve vazifeleri hakkında Kanun" ile kurulan TOPRAKSU Genel Müdürlüğü tarafından kuruluş kanunun amir hükümleri doğrultusunda yapıldığı görülmektedir. Bu çalışmalar ilk defa 1961 yılında Konya ili Çumra ilçesi Kargın köyünde yapılmıştır (Küsek, 2014, s. 4). Ülkede halen de devam eden toplulaştırma çalışmalarının tanımı, kısa tarihçesi ile amaç ve yöntemler ile geniş bilgiler "Türkiye'de Arazi Toplulaştırması" başlıklı ayrı bir bölümde ayrıntılı bir şekilde irdelenecektir.

4753 sayılı kanunla genel olarak hazine arazilerinin dağıtımı yapılmış, buda toprak düzeninde mevcut olan adaletsizliği daha da artmıştır. 1757 Sayılı Kanunun yürürlüğe girdiği 1973 yılına kadar birkaç tarım reform taslağı hazırlanılmış ise de bunlar meclise dahi gelememiştir. Yasanın tam adı "1757 Sayılı Toprak ve Tarım Reformu Yasası "dır. Kanunun uygulanması için Toprak ve Tarım Reformu Müsteşarlığı kurulmuştur. Yürürlüğü döneminde Doğu ve Güneydoğu Anadolu coğrafyasında mevcut toprak dağılımdaki adaletsizliğin giderilmesi ile bu bölgelere yönelik kalkınma modellerinin oluşturulmasının hedeflendiği anlaşılmaktadır. Pilot uygulama Şanlıurfa ilinde başlamış ve 18 doğu ilini kapsayacak şekilde genişlemiştir. Kanunun öngördüğü uygulamaların pek çoğu uygulanamadan, Anayasa Mahkemesince 1978 yılında şekil yönünden iptaline karar verilmiş, düzenleme yapılması için verilen 1 yıllık sürenin sonunda da 10.05.1978 tarihinde yürürlükten kalkmıştır (Alpat, 1975, s. 21-24; Önal, 2010, s. 14; Toklu, 2010, s. 32). 
1978 yılında 1757 sayılı yasanın yürürlükten kalkmasından ve ülkenin içerisinde olduğu politik karmaşanın ardından yaşanan askeri yönetim döneminden sonra tarımda reform adına yeni bir düzenlemenin yapıld1ğ1 görülmektedir. 1984 yılında hayat bulan 3083 sayılı "Sulama Alanlarında Arazi Düzenlenmesine Dair Tarım Reformu Kanunu" un amacı kanunun 1. maddesinde ifade edilmiştir. Bu madde de kanunun öncelikle toprağın verimli şekilde işletilmesini, işletilmesinin korunmasın, birim alandan azami ekonomik verimin alınmasını, tarım üretiminin sürekli olarak artırılmasını, değerlendirilmesini ve buralarda istihdam imkânlarının artırılmasını hedeflediği belirtmektedir. Ayrıca yeterli toprağı bulunmayan ve topraksız çiftçilerin zirai aile işletmeleri kurabilmeleri için Devletin mülkiyetinde bulunan topraklarla topraklandırılmalarını, desteklenmelerini ve eğitilmelerini de amaçlamaktadır. Bununla birlikte ekonomik üretime imkân vermeyecek şekilde parçalanan tarım topraklarının gerektiğinde ve imkânlar ölçüsünde genişletilmesi suretiyle de toplulaştırılmasını, tarım arazisinin ailenin geçimini sağlamaya ve aile iş gücünü değerlendirmeye yeterli olmayacak derecede parçalanmasını ve küçülmesini önlemeyi sağlamak kanunun amaçları arasında sayılmıştır. Yeni yerleşme yerleri kurmayı, mevcut yerleşme yerlerine eklemeler yapmayı, zorunluluk halinde tarım arazisinin diğer amaçlara tahsisini düzenlemeyi, dağıtılmayan tarım arazisinin değerlendirilme şeklini belirlemeyi de amaçlayan kanunun Cumhurbaşkanınca gerekli görülen diğer bölgelerde gayrimenkullerin Milli Güvenlik nedeniyle mülkiyet ve tasarruf şekillerinde ve yerleşim yerlerinde düzenlemeler yapmayı sağlayacağı belirtilmiştir. Kanunun adında önceki uygulamaların aksine "Toprak Reformu" ifadesi kullanılmamaktadır. Ancak içeriği incelendiğinde biçimsel olarak toprak reformu hakkında da hükümler içerdiği ve bu yönü ile şeklî olarak aynı zamanda bir toprak reformu kanunu da olduğunu söylemek mümkündür. Ancak uygulanmasında bu güne kadar herhangi bir toprak dağıtımı ve kamulaştırma yapılmamış olması nedeniyle toprak dağıtımındaki adaleti sağlama noktasında herhangi bir fonksiyonunun olmadığı değerlendirilmektedir (Türker, 2010, s. 54).

19.07.2005 tarihli ve 25880 sayılı resmi gazete yayımlanarak yürürlüğe giren farklı tarihlerde çeşitli değişikliklere uğrayan kanunun amaç ve kapsamını belirleyen 1 . ve 2 . madde metni şu şekildedir. 
1. madde metninde kanunun amacı; toprağın korunması, geliştirilmesi, tarım arazilerinin sınıflandırılması, asgari tarımsal arazi ve yeter gelirli tarımsal arazi büyüklüklerinin belirlenmesi ve bölünmelerinin önlenmesi, tarımsal arazi ve yeter gelirli tarımsal arazilerin çevre öncelikli sürdürülebilir kalkınma ilkesine uygun olarak planlı kullanımını sağlayacak usul ve esasları belirlemek olarak açıklanmıştır.

Kanunun kapsamı hakkındaki 2. maddede ise; arazi ve toprak kaynaklarının bilimsel esaslara uygun olarak sınıflandırılması, tarımsal arazi ve yeter gelirli tarımsal arazilerin asgari büyüklüklerinin belirlenmesi ve bölünmelerinin önlenmesi, arazi kullanım planlarının hazırlanması, koruma ve geliştirme sürecinde toplumsal, ekonomik ve çevresel boyutlarının katılımcı yöntemlerle değerlendirilmesi, amaç dışı ve yanlış kullanımların önlenmesi, korumayı sağlayacak yöntemlerin oluşturulması ile görev, yetki ve sorumluluklara ilişkin usul ve esasları kapsadığı ifade edilmiştir (5403 Sayılı Kanun, 2005).

$\mathrm{Bu}$ kanun ile asgari tarımsal arazi ve yeter gelirli tarımsal arazi kavramları getirilmiş kanun eki 1 sayılı listede ise bölge farklılıkları değerlendirilerek il ve ilçelerin tarım arazisi büyüklük normları belirlenmiş olup; listenin Balıkesir ili ve ilçelerine ait bölümü Balıkesir İli Gönen İlçesi'ne Bağlı Örnek Bir Mahallenin Toplulaştırma Çalışması Örneği başlı̆g altında Tablo 1 olarak verilmiştir.

Türkiye İstatistik Kurumu'nun "Tarımsal İşletme Yapı İstatistikleri” 'nden elde edilen veriler, Türkiye'deki tarımsal işletme malik sayısının yaklaşık 40 milyon olduğunu, bu maliklerin yine yaklaşık olarak 3 milyonunun aktif tarımsal işletmeleri oluşturduğu anlaşılmaktadır. Bu bağlamda her 13 malikin tarımsal arazisinin 1 kişi tarafından işletildiği sonucuna ulaşılmaktadır. Ortalama tarımsal işletme büyüklügünün ülkemizde 59 dönüm civarında olmasına karşın, bu miktarın Avrupa Birliği ülkelerinde ortalama 126 dönüm olduğu, Amerika Birleşik Devletlerinde ise 181 dönüme ulaştığ görülmektedir (Küsek, 2014, s. 2; Yavuz ve Topuz, 2015, s. 664). 


\section{Toprak Reformu Çerçevesinde Türkiye'de Arazi Toplulaştırması}

Arazi toplulaştırması, yeterli işletme büyüklüğüne sahip olmayan tarım arazilerinin belirli yöntemler yardımıyla uygun tarım arazisi büyüklüklerine ulaştırılması çalışmalarının bütünü olarak tanımlanabilir. Arazi Toplulaştırma Uygulama Yönetmeliği (2017) ile Arazi Toplulaştırması ve Tarla İçi Geliştirme Hizmetleri Uygulama Yönetmeliği (2019)'nde “Arazi toplulaştırması: Arazilerin doğal ve yapay etkilerle bozulmasını ve parçalanmasını önlemek, parçalanmış arazilerde ise doğal özellikleri, kullanım bütünlüğ̈̈ ve mülkiyet hakları gözetilerek birden fazla arazi parçasının birleştirilip ekonomik, ekolojik ve toplumsal yönden daha işlevsel yeni parsellerin oluşturulmasını ve bu parsellerin arazi özellikleri ve alanı değerlendirilerek kullanım şekillerinin belirlenmesini ve arazi gelişimi hizmetlerinin sağlanması" şeklinde tanımlamaktadır.

İki tür yöntem uygulanarak dar ve geniş anlamda arazi toplulaştırması yapılması mümkündür. Dar anlamda arazi toplulaştırmasında, aynı kişi ya da işletmeye ait geometrik bozukluk, dağınıklık veya parça miktarının küçük olmaları gibi nedenlerle tarımı verimli yapmaya imkân vermeyen tarımsal arazilerin, verimli tarım yapmaya uygun miktar ve şekiller oluşturularak bir araya getirilmesidir. Geniş anlamda arazi toplulaştırması ise, tarla içi geliştirme hizmetleri ile birlikte yukarıda tarif edilen dar anlamda arazi toplulaştırma işlemlerinin birlikte yürütülmesidir (Demirtaş, Sarı, Sönmez ve Altunbaş, 2016, s. 17; Küsek, 2014, s. 2).

Tarımsal işletmelerde verimliliği düşüren nedenler olarak; mülkiyetin miras ve intikal nedeniyle çok hisseli hale gelmesi, hisselerin bölünmesi suretiyle yapılan satış işlemleri, yeterli olmayan arazilerin bir de kısmı olarak ortakçılık veya yarıcılık faaliyetlerine konu edilmesi, çeşitli kamu yatırımları amacıyla kamulaştırma çalışmaları neticesinde arazinin bütünlüğünün bozulması söylenebilir. Bunun ortadan kaldırılması için yapılan arazi toplulaştırmasının amaçlarını şu şekilde sıralamak mümkündür (Küsek, 2014, s. 3): Fiziki tesislerin sebep olduğu parçalanmaları önleyerek bu sayede sulama projelerinin maliyetinde tasarruf sağlanmak, sulama ve teknik tarım metotlarının uygulanmasını kolaylaştırmak, ayrıca arazi sahiplerine kamulaştırma bedeli yerine arazi vererek, onların toprağından kopmasını önlemek, işletme merkezi ile parseller arasındaki mesafeleri azaltarak, her parseli yola bağlamak, işletmede iş gücü tasarrufu sağlamak, net arazi kullanma alanı ve parsel büyüklüklerini artır- 
mak, parsel şekillerini düzeltmek bu sayede işletmede net gelir artı̧̧ı sağlayarak proje alanında sosyal huzur sağlanmak.

Arazi toplulaştırmasının sağlayacağı faydaları sosyal ve ekonomik faydalar olarak iki grupta incelemek mümkündür.

Arazi toplulaştırmasının sağlayacağı sosyal faydalar

- Tarım arazilerinin toplulaştırması kırsaldan kente göçün yavaşlaması, hatta tersine döndürülmesini sağlayabilecek bir planlamadır.

- Öncelikle proje ile üretilen yeni tarım arazilerinin tümü yol ve sulama kanallarında direkt olarak istifade edebilmektedir. İşletmeler arası anlaşmazlık ve huzursuzluk nedeni olan azami ölçüde yol ve sulama imkânlarından yararlanamamayı ortadan kaldırmaktadır.

- Gerek miras yolu ile çok hissedarlı hale gelen ya da bölünen gerekse evvelden beri çok hisseli olarak tasarruf edilen tarım arazilerindeki hissedarlara, hisselerinin birleştirilmesi ile projenin el verdiği ölçülerde müstakil tapular verilmektedir. Güncellenen kadastro bilgileri ile yenilenen tapu bilgileri sayesinde bu alanlardaki tapu ve kadastro problemleri azami düzeye inmektedir.

- Yerleşim yerlerinin yeniden düzenlenmesi ile üretim faktörlerinin yanında arazi - yerleşim yerleri arasındaki trafik düzenlenmekte bunun yanı sıra yeni sosyal alanların kazandırılmaktadır.

- Mera arazileri üzerinde gerçekleşmiş olan işgal, konut yapımı vb. hukuksuz fiillerin ortadan kaldırılması amaciyla buraları terk etmeleri karşılığında kişilere hazine veya şahıs arazileri verilmek suretiyle mera alanlarının gerçek amacı ile kullanılması sağlanırken, hukuksuzlukların ortadan kaldırılması sağlanmaktadır (Boyraz ve Üstüntaş, 2008, s. 569; Küsek, 2014, s. 3; Özer, 2010, s. 8-9).

Arazi toplulaştırmasının sağlayacağı ekonomik faydalar

- Arazi toplulaştırma çalışmaları ile birlikte sürdürülen drenaj, sulama ve tesviye faaliyetleri sayesinde tarım arazilerine ulaşım kolaylaşmakta, sulama maliyetlerinin de düşmesini sağlamaktadır.

- Toplulaştırma alanı içerisinde yer alacak olan devlet yatırımlarının yapılacağı araziler için kamulaştırma bedeli ödenmemekte, bu sayede devletin bu projelere ayırması gereken bütçeler küçülmektedir.

- Tarımsal arazilerinden merkezlere ve tarım arazileri arası ulaşım yollarının toplulaştırma projeleri sayesinde kısalması sayesinde hem vakit hem de yakıt tasarrufu sağlanarak maliyetler düşmektedir. 
- Toplulaştırma ile yeni oluşturulan parsellerin geometrik olarak düzgün şekillerde olması tarım araçları ile daha verimli bir çalışmaya imkân vermekte buda verimin artması ile birlikte gelirin de artmasına yol açmaktadır (Boyraz ve Üstüntaş, 2008, s. 569; Küsek, 2014, s. 3; Özer, 2010, s. 8-9).

Arazi toplulaştırma çalışmalarının sosyal ve ekonomik yönden tarım alanların bulunduğu yerlerde yaşamını sürdüren kişiler açısından son derece önemli ve olumlu sonuçlar oluşturduğu anlaşılmaktadır. Tarım arazilerinin toplulaştırılması çalışmalarının fiilen sağladıkları konusunda daha aydınlatıcı bir fikir oluşması bağlamında Balıkesir ili Gönen İlçesi'ne bağlı bir mahalle örnek olarak alınacak, burada (6360 Sayılı Kanun ile Büyükşehir olan illerin tüm köyleri tüzel kişiliklerini kaybederek mahalle haline gelmiştir. 6360 sayılı kanundan önce köy olan mahalleler "Kırsal Mahalle" olarak anılacaktır) yapılan toplulaştırma çalışması örneği irdelenecektir.

\section{Balıkesir İli Gönen İlçesi'ne Bağlı Bir Mahallenin Toplulaştırma Çalışması Ömeği}

Örnek kırsal mahalle Gönen ilçesine yaklaşık 5,5 km mesafede 269 nüfuslu bir yerleşimdir. 04/12/2008 tarihli ve 2008/14338 sayılı bakanlar kurulu kararnamesi eki listede yer ve sınırları belirlenen 3551 hektar büyüklüğündeki toplulaştırma projesi kapsamında (Resmi Gazete, 2008; 27074) bu kırsal mahallede 2018-2019 yıllarında toplulaştırma işlemler yapılmış, halen toplulaştırma projesinin tescil işlemleri devam etmektedir.

Belirlenen toplulaştırma alanı içerisinde 623 adet kadastro parseli uygulamaya girmiştir. Uygulamada 58 adet ada oluşturularak 423 adet parsel üretilmiştir. Ortalama parsel alanları uygulamadan önce 6,79 dekar nispetindeyken, uygulama neticesinde bu oran 10,14 dekar seviyesine çıkmıştır. Ulaşım sistemi içerisindeki yol miktarı 9.639 m'den 18.505 m’ye çıkarılmıştır. Ulaşım sisteminde yararlanan parsel sayısı uygulama öncesi 135 iken bu sayı uygulama neticesinde 423'e çımış yanı oluşan tüm parsellerin ulaşım sisteminden yararlanması sağlanmıştır. Proje alanında toplulaştırmadan önce sulama ve drenaj sistemi bulunmaz iken, uygulama ile birlikte $12.262 \mathrm{~m}$ sulama, $2.637 \mathrm{~m}$ drenaj sistemi oluşturulmuştur. Uygulama alanındaki kadastro parsellerinin eski mülkiyet durumunu gösterir harita Ek. 1 de verilmiştir. 
Haritanın tetkikinden geometrik olarak düzgün bir şekle sahip parselin bulunmadığı, bir kısım parsellerin ulaşım imkânlarının bulunmadığı, büyüklük olarak belirli bir standart olmadığı görülmektedir. Proje alanı içerisindeki parsellerin yüzölçümü olarak küçüklüğü dikkat çekmektedir. Proje alanının orta kısmına isabet eden alanda daha yoğun olarak küçük yüzölçümlü parsellerin bulunduğu gözlenmektedir. Proje alanı örnek kırsal mahalle yerleşim alanından başlayarak Kuzeyde orman, Batıda ve Doğuda başka kırsal mahalleler toplulaştırma projesi alanları ile sınırlandığı anlaşılmaktadır.

Ek.2 de yer alan ada (Blok) bölüm haritasından görüleceği gibi proje alaninda 163 den başlayarak 221'e kadar numara alan 58 adet blok oluşturulmuştur. Daha sonra bu bloklar kendi içlerinde her bir parsele ulaşım imkânı sağlayacak şekilde, proje için belirlene arazi değeri, mülkiyet birleştirme ve zayiat oranları dikkate alınarak bölünmektedir.

Ek.3 te verilen eski - yeni çakışık mülkiyet haritasında ise uygulama neticesinde oluşan yeni parsellerin ve eski parsellerin durumların bir arada görme imkânı bulunmaktadır. Görüldüğü üzere yeni oluşan parsellerin tümünün ulaşım imkânlarından istifade ettiği, parsellerin geometrik olarak düzgün şekillerden oluşturulduğu anlaşılmaktadır. Haritaların iki boyutlu olması nedeniyle arazinin topoğrafyası konusunda bilgi edinme imkânı bulunmamaktadır. Uygulanan toplulaştırma projelerinde 5403 sayılı kanun ile belirlenen toprak miktarı normlarına uygun tarımsal büküklükte arazi parçalarının oluşturulamadığı görülmektedir.

Tablo 1. Balıkesir ili ilçelerinin arazi miktarları

\begin{tabular}{lcccc}
\hline İlçe & $\begin{array}{l}\text { Sulu Arazi } \\
(\mathbf{D a})\end{array}$ & $\begin{array}{l}\text { Kuru Arazi } \\
(\mathbf{D a})\end{array}$ & $\begin{array}{l}\text { Dikili Arazi } \\
(\mathbf{D a})\end{array}$ & $\begin{array}{l}\text { Örtüalti Arazi (Da) } \\
\text { Ayvalık }\end{array}$ \\
\hline Balya & 100 & 140 & 10 & 3 \\
\hline Bandırma & 60 & 200 & 10 & 3 \\
\hline Bigadiç & 70 & 140 & 10 & 3 \\
\hline Burhaniye & 70 & 160 & 10 & 3 \\
\hline Dursunbey & 100 & 170 & 10 & 3 \\
\hline Edremit & 60 & 200 & 10 & 3 \\
\hline Erdek & 60 & 120 & 10 & 3 \\
\hline Gömeç & 60 & 180 & 10 & 3 \\
\hline Gönen & 80 & 170 & 10 & 3 \\
\hline Havran & 80 & 170 & 10 & 3 \\
\hline İvrindi & 90 & 180 & 10 & 3 \\
\hline Kepsut & 80 & 170 & 10 & 3 \\
\hline Manyas & 80 & 170 & 10 & 3 \\
\hline
\end{tabular}




\begin{tabular}{lllll}
\hline Marmara & 80 & 170 & 10 & 3 \\
\hline Merkez & 80 & 170 & 10 & 3 \\
\hline Savaştepe & 80 & 170 & 10 & 3 \\
\hline Sindırg1 & 80 & 200 & 10 & 3 \\
\hline Susurluk & 80 & 170 & 10 & 3 \\
\hline
\end{tabular}

5403 Sayılı Toprak Koruma ve Arazi Kullanımı Kanunu.

\section{Gözlemler}

- Projeye ait Ek.1 de verilen haritanın tetkikinden gerçekten arazinin çok parçalı, ulaşım ve sulama imkânı olmayan parsellerin bulunduğu, geometrik olarak düzgün şekilli parça sayısının nereyse yok olduğu anlaşılmaktadır. Bu alanın toplulaştırmanın amaçlarına uygun ve mutlaka toplulaştırma çalışması yapılması gereken bir yapının olduğu muhakkaktır.

- Çalışma ekindeki Ek.3 haritanın tetkikinden bu defa geometrik olarak çok düzgün şekiller içeren, tümünün sulama ve ulaşım imkânlarına sahip olduğu tarımsal parsellerin oluşturulduğu, toplulaştırmanın genel amaçlarından olan bozuklukların düzeltilesinin sağlandığ görülmektedir.

- Ancak bu haritada dikkatimizi çeken bir husus bazı bloklarda (bunlar ada olarak adlandırılmakta ve numaralandırılmaktadır), bazı parsellerin yüzölçümlerinin çok küçük tutulmuş olmasıdır. Örnek: 170 ada 5-6-7-9-11-12 parseller. 5 parsel 905,82 $\mathrm{m}^{2}, 6$ parsel 1041,47 m², 7 parsel $935,56 \mathrm{~m}^{2}, 11$ parsel $571,93 \mathrm{~m}^{2}$ ve 12 parselin de 548,38 miktarında ve tarla vasfında olduğu görülmektedir. Benzer şekilde; 190 ada 1 ve parseller, 201 ada 8 ve 11 parseller, 202 ada 2 ve 4 parsellerin yüzölçümlerinin $1000 \mathrm{~m}^{2}$ nin altında olduğu görülmektedir. Bu örnekler bu proje bazında çoğaltmak mümkündür.

- Ek.3 harita da projenin sadece ada bazında hazırlanan ve parsel s1nırları oluşturulmamış hali görülmektedir. Birkaç proje sınırına, yol ve sulama kanallarının kesişim noktalarına rast gelmeleri nedeniyle oluşan küçük yüzölçümlü alanların dişında düzgün geometrik şekillere sahip alanların oluştuğu görülmektedir.

Genel hatları ile örnek kırsal mahalle toplulaştırma projesinin toplulaştırma amaçlarına uygun bir uygulama olduğu görülmekle birlikte, bu ve benzeri uygulamalar konusundaki eleştiri ve önerilerimiz çalışmanın sonuç ve öneriler bölümünde ele alınacaktır. 


\section{Konunun Örnek Mahallede Mülakat Yoluyla İrdelenmesi}

Örnek kırsal mahalle mukimlerine nitel araştırma yöntemlerinden olan yarı yapılandırılmış mülakat soruları yönlendirilerek makale konusu irdelenmiştir. Mevcut literatürden yararlanılarak konuyla ilgili 6 adet mülakat sorusu çıkarılmıştır. Bu sorular;

1. Tarımsal toprakların daha fazla kullanılması Türkiye açısından önem arz etmekte midir? Neden?

2. Türkiye'deki tarımsal işletme sayıları ve büyüklükleri yeterli midir? Yeterli değilse neler yapılmalıdır?

3. Türkiye'deki küçük ve çok parçalı toprak yapısının ana etkenleri nelerdir?

4. Küçük ve çok parçalı toprak yapısının önüne nasıl geçilebilir?

5. Türkiye'de toprak reformu konusunda yeterince yasal düzenleme var mıdır? Olan yasal düzenlemeler sizce yeterli midir? Neden?

6. Toprak reformu kapsamında önerileriniz nelerdir?

şeklindedir. Mülakat sorularına verilen cevaplar ise şu şekilde olmuş, katılımcıların sadece isim ve soyisim ilk harfleri verilmiştir.

1.soruya "Ülkemiz matematik ve coğrafi konum itibariyle tarımsal faaliyetlerden en fazla verim alabilecek ülkelerden biridir. Ancak gerek miras hukukundan kaynaklanan gerek üretim maliyetleri nedeniyle tarımsal faaliyetler yeteri kadar ilgi görmemekte ve birçok tarım arazisi atıl vaziyette durmaktadır. Ancak tarım, teknolojinin de gelişmesiyle en verimli şekilde kullanılması durumunda hem ülke ekonomisine hem de bireylerin (ailelerin) geçimine önemli katkıda bulunabilir. Ülkemizin gelişmekte olan ülkeler arasında günümüzde teknolojik atılımlarla yerini almaya çalışmakta ancak yeterli değildir. Tarım faaliyetleri göz ardı edilmeden gerçekleştirilecek yatırımlar sadece bireylerin geçimi ile ilgili değil, ülkenin ekonomisinde de önemli pay sahibidir."( $\mathrm{I}^{* * *} \mathrm{Y}^{* * *}$ ), “Önem arz etmektedir. Bir ülke kendi tarımsal ürünlerini kendisi üretip, kendi kendine yetebilen bir ülke olduğunda dışa bağımlılıktan kurtulur. Kendi ürettiğimizi kendimiz tükettiğimiz zaman hem kaliteli hem de ucuz gıda kullanırız." (Ö $\left.{ }^{* * *} C^{* * *}\right)$, “Evet. Türkiye'nin gelir kaynağının çoğu tarımdan sağlanmaktadır. Diğer ekonomik ve teknolojik sistemler yurtdışı desteklidir." $\left(E^{* * *} C^{* * *}\right)$, “Tarımsal toprakların daha fazla kullanılması ve verimli kullanılması Türkiye'nin ekonomisi açısından çok önemlidir. $\left(\mathrm{V}^{* * *} \mathrm{H}^{* * *}\right)$, “Evet, verimli topraklar ve su kaynaklarının bulunması dolayısı ile sulu ve susuz tarım imkânı çok fazladır. Bu toprakların kul- 
lanımı ülke için önemlidir." $\left(\mathrm{N}^{* * *} \mathrm{H}^{* * *}\right)$ şeklinde cevaplarını vermişlerdir. 2. soruya "Türkiye'de kurulu tarımsal işletmeler, kooperatifler ya da birliklerin yeterli olmadığı kanaatindeyim. Yapılması gereken her iklimin her toprağın ayrı ayrı değerlendirilerek, faaliyetlerini bir bütün halinde gerçekleştirilmesinin sağlanmasıdır. Kooperatifleşme, bir çok il ve ilçede rant kapısı olarak değerlendirilmektedir. Elbette gerçek anlamda işini hakkını vererek kurumsallaşan kooperatifler ya da firmalar vardır. Denetim mekanizmasının iyi bir şekilde işletilmesinin yanı sıra bu birim ya da firmaların ülke çıkarlarını gözeterek faaliyetlerini sürdürmeleri gereklidir kanaatindeyim." (i*** $\left.\mathrm{Y}^{* * *}\right)$, “Tarımsal alanlar bence yeterli ama ülkemizin can damarı ovaları ile ünlü Konya ovası gibi toprağın özelliğini kaybettiği yerlerde çeşitli önlemler ve yatırımlar yapılarak daha verimli hale getirilip ürün çeşitliliği artırılabilir. Ormanları tahrip edilip tarım arazisine dönüştürülmesine karşıyım."(Ö*** Ç⿻*), “Tarımsal işletme sayıları ve büyüklükleri yeterli değildir. Amerika ve Avrupa'nın şu an uyguladığ tarım politikasında kişisel üretim ve kişisel çalışmadan çok şirketler, vakıflar ve kooperatifler tarım arazilerini işlenmektedir. Üretim, arazinin işlenmesi, ürünlere bakım, ilaçlama, gübreleme teknolojik aletlerle yapılmaktadır. Üretilen ürünler daha fazla verimli olmaktadır." (E** $\left.C^{* * *}\right)$, “Türkiye'deki tarımsal işletme büyüklükleri neredeyse hobi bahçesine dönüşmüş durumda. Tarımsal işletmelerin en azından köy ya da mahalle bazında bir araya toplanmalıdır." $\left(\mathrm{V}^{* * *} \mathrm{H}^{* * *}\right)$, "Yeterli olduğunu düşünmüyorum.. Tekelleşmeye gidilmeden tek elden ve büyük arazilerde tarım yapılmasının zaman ve işçilik açısından faydalı olacaktır." $\left(\mathrm{N}^{* * *} \mathrm{H}^{* * *}\right)$ şeklinde cevaplarını vermişlerdir. 3.soruya "Ülkemiz arazi yapısı miras hukuku nedeniyle fazlasıyla parçalanmakta ve amacı dışında kullanılmaktadır. En büyük etken bu olarak görünse de, şehirleşmenin getirdiği kent hayatından uzak kalma dürtüsüyle toprakla uğraşmak istemektedir. Sonuç olarak büyük bir araziyle uğraşmak yerine parçalar halinde pazarlanan taşınmazlara yönelinilmektedir." ('ं*** $\left.\mathrm{Y}^{* * *}\right)$, "Coğrafi koşullar en büyük etken, her bölge ovalık değil, ikinci husus miras yoluyla intikal ettirilen taşınmazların mirasçılar arasında parça parça olarak kullanılması." (Ö*** Ç $\left.{ }^{* * *}\right)$, "Mirasta her mirasçının toprak almasıyla zamanla araziler küçülmekte ve küçük araziyi ekmek, dikmek, bakımını yapmak zamanla ürünlerin masrafı karşılamaz hale gelmesine neden olmakta bu yüzden de araziler boş kalmaktadır."( $\mathrm{E}^{* * *}$ Ç $\left.^{* * *}\right)$, "Türkiye'deki toprak parçalarının küçük ve parçalı olması toprak 
maliklerinin ölümü sonucu taşınmazların tarımla uğraşan kişilere aktarılmaması, anlaşılamaması sonucu toprak bütünlüğü sağlanamamaktadır." $\left(\mathrm{V}^{* * *} \mathrm{H}^{* * *}\right)$, "Tarım arazilerinin miras yolu ile paylaşılması parçalı yapının temel sebebidir." $\left(\mathrm{N}^{* * *} \mathrm{H}^{* * *}\right)$ şeklinde cevaplarını vermişlerdir. 4.soruya "5403 Sayılı Toprak Koruma ve Arazi Kullanımı Kanununun amacı özünde tarım arazilerinin bir bütün halinde mümkün olduğunca tek bir birey ya da işletme eliyle işletilmesini sağlamaktır. Ancak gerek ülkenin ekonomik durumu gerekse aile içi paylaşımın gerekli zamanda ve şekilde paylaşılmaması kanunun önünde engel teşkil etmektedir. Elbette yeni bir duruma geçiş kolay olmayacaktır. 2007 yılında başlayan süreç günümüze kadar birçok defa değişiklik göstererek gelinmiştir. Tarım arazilerinde tek malikli mülkiyet esası benimsenerek mirasa konu olduğu andan itibaren taşınmazların intikalinin doğrudan anlaşılarak bir mirasçıya geçmesi sağlanmalıdır." (I*** $\mathrm{Y}^{* * *}$ ), “Devletin toplulaştırma yöntemiyle tarım arazilerini çok parçalı ve çok hisseli olan yerleri bir araya getirerek mümkünse müstakil hissesiz hale getirmesidir."(Ö*** $\left.C^{* * *}\right)$, "Tarımla uğraşan şirketler, kooperatifler gerekirse vakıflar kurulması, tarımın işlenmesi kişiselleşmekten kurtarılmalıdır." $\left(E^{* * *} C^{* * *}\right)$, "Kesin ve kati Tarım Kanunu çıkarılarak taşınmazların minimum kişilere ve tarım işleri yapacak kişilere kalması sağlanmalıdır." $\left(\mathrm{V}^{* * *} \mathrm{H}^{* * *}\right)$, "Gerekli yasal düzenlemeler, bölgesel tarıma uygun arazi büyüklüklerinin oluşturulması ve tarımın bir bütün olarak yapılması." $\left(\mathrm{N}^{* * *} \mathrm{H}^{* * *}\right)$ şeklinde cevaplarını vermişlerdir. 5.soruya "Reformlar konusunda çalışmalar vardır. Ancak yeterli kalmamaktadır. Bunun sebebi tarım arazilerinin paylaşımının ekonomik nedenle gerçekleşememesidir. Gerçekleştirilen arazi düzenlemesi (toplulaştırma) çalışmaları özünde olması gerektiği gibi gerçekleşmemektedir. Yine karşımıza arazi paylaşımı konusunda anlaşmazlıklar çıkmaktadır." (i*** $\mathrm{Y}^{* * *}$ ), "Toprak reformu konusunda yapılan düzenlemeler zaman zaman çiftçiyi zor duruma düşürerek küçük çiftçinin zararına olup, büyük toprak sahiplerinin lehine olmaktadır. Kanunun eşit şekilde herkesi koruması gerekir." $\left(\ddot{O}^{* * *} C^{* * *}\right)$, "Yasal düzenlemeler yıllardır var ama verimli sonuçlar alınmayınca kanunlar sürekli değişiklik göstermektedir. Mevcut yasalar halen yeterli değildir. Toprak bütünlüğünü sağlayacak ve ekilmeyen arazilerin kamulaştırmaya benzer sistemle zorunlu gerekirse kiralanmak suretiyle işlenmesini sağlayacak bir yapı oluşturulması konusuna el atılmalıdır." $\left(E^{* * *} C^{* * *}\right)$, "Türkiye'deki toprak reformu yeterli sonucu vermemektedir. Taşınmazların tarım dışında ticari amaçlı olarak kullanılmakta- 
dır." $\left(\mathrm{V}^{* * *} \mathrm{H}^{* * *}\right)$, “Yeni yasal düzenlemelere ihtiyaç var. Özellikle miras nedeniyle tarım arazilerinin bölünmesinin önüne geçecek köklü değişikliklere ihtiyaç vardır." $\left(\mathrm{N}^{* * *} \mathrm{H}^{* * *}\right)$ şeklinde cevaplarını vermişlerdir. 6 . soruya "Arazi düzenlemeleri tarım ile uğraşan birden fazla mekânda küçük parçalar halinde değil, bir bütün halinde tek bir mekânda arazinin olması şeklinde yapılmalıdır. Miras paylaşımı esnasında birden fazla mirasçının adına intikal değil, her taşınmazın bir mirasçının olması şeklinde intikallerin gerçekleşmesi gerekir. Bu konuda 5403 yasası katı bir uygulamaya neden olmaktadır. Bir taşınmaz bir mirasçının olacak şekilde intikal yapılmalıdır. Terekenin tek mirasçıda toplanması ülkemiz şartlarında uygulanmasında sorunlara neden olacaktır. Arazi büyüklükleri miras paylaşımını engelleyecek şekilde oluşmuş durumdadır. Mirastan gelen ve farklı büyüklüklerdeki taşınmazların paylaşımında büyüklük normuna göre değil bölünmeden teker teker taşınmazların mirasçılara paylaştırılması yöntemi benimsenmeli ve kanuni düzenlemeler buna göre olmalıdır." (Iं*** $\left.Y^{* * *}\right)$, "Bence toprakları ekenlere, tarım ile uğraşanlara öncelik verilmeli, en önemlisi de ekim yapılan ürünlerin belli bir plan çerçevesinde yapılıp, çiftçinin emeğinin boşa gitmemesini sağlamal. Herkes ayn ürünü ektiğinde bir üründe bolluk olurken, diğer bir üründe kıtlık yaşanmaktadır. Çiftçiliğin gerçek bir meslek haline gelip, herkesin her üründe kâr edebileceği, kendini geçindirebileceği bir hale getirilmeli." (Ö*** Ç***), "Temeli Osmanlı sistemine dayanan bugün Amerika ve Avrupa'nın kullandığı tarım politikasının uygulanmasına geçilmesini öneriyorum." $\left.\mathrm{E}^{* * *} \mathrm{C}^{* * *}\right)$, "Reform olarak tarım arazileri en azından mahalle veya köy bazında tek parça olarak kullanılmalı, malikler hisselere bölünmemeli, malikler değişse bile tarım terk edilmemelidir. Yani ne olursa olsun tarım arazisi atıl kalmamalı, işlenmeli ve üretime kaynak sağlanmalıdır." $\left(\mathrm{V}^{* * *} \mathrm{H}^{* * *}\right)$, “Tarım arazilerinin bu işi yapan, yapacak olan kişilerin yani çiftçilerin mülkiyetinde ya da kullanımında olması gerekiyor. Büyük tarım arazilerinde teknolojik imkânlarla verimli üretim yapmalarını sağlayacak ekonomik ve yasal düzenlemelerin yapılması gerekiyor. Bu durumda ülke tarımı ileri bir seviyeye ulaşacaktır." $\left(\mathrm{N}^{* * *} \mathrm{H}^{* * *}\right)$ şeklinde cevaplarını vermişlerdir.

Verilen cevaplar aynileşmeye başladığından 5. Katılımcıdan itibaren mülakat sonlandırılmıştır.

Mülakat sonucunda Türkiye'de tarımsal toprakların daha fazla kullanılmasının ekonomi, kaliteli üretim ve ucuzluk açısından önem arz ettiği, 
ancak miras hukukunun ve üretim maliyetlerinin fazlalığının tarımsal üretimin gelişmesine engel olduğu, çok parçalı tarımın üretime ciddi engel oluşturduğu, bu çok parçalı toprak yapısının kooperatifler, birlikler ve vakıflar yoluyla bir bütün şeklinde işlenebileceği, parçalı toprak yapısının ana etkeninin miras hukuku olduğu ve mirasçıların üretim için anlaşma yolunu tercih etmemelerinin büyük bir sorun olduğu, tarım arazilerinde tek malikli mülkiyet esasının benimsenerek arazilerin mirasa konu olduğu andan itibaren taşınmazların intikalinin doğrudan anlaşılarak tarımla uğraşacak bir tarafa geçmesinin sağlanması ve gerekirse bu amaçla kanuni düzenlemelerin yapılması, gerekli yasaların toplulaştırma ve tarım arazilerinin verimli işletilmesi için yeterli olmadığı, zorunluluk şeklinde toprak maliklerini toplulaştırmaya ve tarımsal üretime yönlendirecek yasaların çıkarılması gerektiği konularında bir mutakabat olduğu görülmüştür.

Toprak reformu kapsamında çeşitli mekanizmalarla toplulaştırmanın öncelenmesi, mirasın paylaşımının tarımsal üretimi azaltmayacak şekilde düzenlemelerle yeniden yapılandırılması önerileri öne çıkmıştır.

Çalışmada yer verilen örnek Balıkesir ili Gönen İlçesi örnek bir kırsal mahallede uygulanan projenin tetkikinden ulaşılan sonuçlar ve önerileriler şu şekilde ifade edilebilir:

\section{Sonuç ve Öneriler}

Toprak ve toprak mülkiyetinin tarih boyunca geçirdiği değişimler, beraberinde ülkeler bazında farklılıklar göstermekle birlikte adil olmayan bir dağılıma neden olduğu görülmektedir. Tarihin ilk dönemlerinde toplayıcılıktan vazgeçerek tarım yapmaya başlayan insanoğlu, tarım yaptığ bu toprakların çevrelerinde yaşamaya başlayarak ilk yerleşimlerin de kurulmasını sağlamışlardır. Zaman içerisinde toprak dağılımındaki denge güç odaklı olarak değişmeye başlamıştır. Toprak zengin ve güçlülerin elinde birikmiştir. Diğer insanlar ise bu toprak sahiplerine hizmet eden kimi zaman köle, kimi zaman serf, kimi zaman da maraba olmuştur. Topraksız ya da geçimine yetecek kadar toprağı olmayanlar ile toprakların büyük bölümünü elinde bulunduranlar arasında anlaşmazlıkların yaşandığı, bu anlaşmazlıkların sonucu savaşların çıktığı konusunda tarihte pek çok olaya rastlanmaktadır.

Toprak dağılımındaki adaletsizliği gidermek maksadıyla bilinen ilk yasaların MÖ 800 yıllarında yazıldığı görülmektedir. Günümüzden yak- 
laşık 2800 yıl öncesinde toprak dağılımındaki adaletsizliği gidermeyi amaçlayan ilk toprak reformu yasalarının yapıldığı düşünüldüğünde, halen bu konunun tartışılıyor olması çözüm konusunda karşılaşılan direncin de bir göstergesi olduğunu söylemek yanlış olmayacaktır. Toprak reformu konusunda modern anlamdaki uygulamaların Avrupa Kitasında 1800'lü yılların başlarında, Rusya'da 1800'lü yılların ortalarında, Latin Amerika ve Güney Asya ülkelerinde genel olarak 20. yüzyılın ortalarında başladığı görülmektedir. Ortadoğu ve Mısırda 1950'li yıllarda toprak reformu konusunda çalışmalar yapıldığı görülmektedir.

Türkiye'de Osmanlı Devleti döneminde 1858 yılında yürürlüğe konulan Arazi Kanununun genel olarak tarım arazilerinin amacı dışında kullanılmamasına, tarım arazilerinin belirli kişi ya da zümrelerin elinde toplanmasını önlemeye yönelik hükümleri itibariyle ilk toprak reformu kanunu olarak kabul etmek mümkündür. Osmanlı Devletinin yıkılması ile birlikte kurulan yeni Türkiye Cumhuriyetinde toprak konusundaki ilk kanun metinleri olarak 1924 Anayasası, 1925 Kadastro Kanunu, 1926 Medeni Kanunu gösterilebilir. Daha önceleri zilyetlik hükümlerine göre tarım arazilerini kullanan kişilerin Medeni Kanunun kabulü ile mülkiyet haklarını tapuya tescil ettirebilme olanakları doğmuştur. Cumhuriyet öncesinde, yaşadıkları dönemlerin koşulları ile büyük topraklara sahip kişiler oluşmuş, bunların birçoğunun ülkenin kurtulmasını ve Cumhuriyetin kurulmasını sağlayan Kurtuluş Savaşına büyük katkıları olmuştur. Bu nedenle Türkiye'de bu kitlenin etkilenmesi kesin olarak görülen toprak reformu çalışmaları için 1933-1934 yıllarının beklenmesi gerekmiştir.

2510 sayılı İskân Kanunu ile 1934 yılında özellikle kırsal alanlarda oluşan ağa-yarıcı, maraba, ortakçı şeklindeki üretim faaliyetlerinin tasfiyesinin amaçlandığı anlaşılmaktadır. 1935 yılında Atatürk'ün talimatı ile Zirai Islahat Kanunu çalışmaları başlamışsa da bu çalışmaların kanunlaşamadığ 1 görülmektedir. Toprak reformu ile birlikte tarımsal faaliyetler konusunda köylülerin bilinçlendirilmesi amacıyla başlatılan köy enstitüleri projesinin de politik hesaplar, büyük toprak sahiplerinin yoğun muhalefetleri neticesinde amacını gerçekleştiremeden sona erdirildiği görülmektedir. İkinci Dünya savaşının patlak vermesi yapılmaya çalışan toprak reformu çalışmalarının ertelenmesine neden olmuştur.

4573 sayılı "Çiftçiyi Topraklandırma Kanunu" toprak dağılımındaki adaletsizliği çözmek, topraksız çiftçiyi topraklandırmak, toprağı olup işletme kuramayanlara kredi sağlayarak verimli tarım yapmalarını sağ- 
lamak, bu çalışmalar için gerekli görüldügünde kamulaştırma yaparak büyük arazi sahiplerinin topraklarının da dağıtılması olarak özetlenebilir. 1945 yılında yürürlüğe giren kanun 1973 yılında ki 1757 sayılı “Toprak ve Tarım Reformu" yasasına kadar yürürlükte kalmasına karşın amaçlanan reformları gerçekleştirmekten uzak kalmıştır. 1757 sayılı kanunun da Anayasa Mahkemesinin iptal kararı ile ortadan kalkmasına kadar geçen sürede toprak reformu çalışmaları anlamında herhangi önemli uygulamaya rastlanılamamaktadır.

1984 yılında adında toprak reformu isminin kullanılmadığı reform yasası yürürlüğe girmiştir. İçerdiği hükümler itibariyle aynı zamanda bir toprak reformu kanunu olan "Sulama Alanlarında Arazi Düzenlemesine Dair Reform Kanunu" ile günümüze kadar toprak reformu adına herhangi bir uygulama hayata geçirilmemiştir. Bundan sonraki süreçte tarım yapılan arazilerin verimli kullanılmasına, parçalı bir görüntü sergileyen toprakların daha küçük parçalara ayrılmasını önleyici mevzuat çalışmalarının yapıldığı görülmektedir. 2005 yılında 5403 sayılı kanun yayımlanmış, tüm il ve ilçelerin tarım arazilerine büyüklük normları getirilerek, arazilerin bu normların altında bölünemeyeceği hükmü getirilmiştir. Kanun ile getirilen normlara uygun olmayan parçalanmış arazilerin yeter büyüklüklere ulaştırılması açısında toplulaştırma çalışmaları büyük önem kazanmıştır.

Toplulaştırma çalışmaları ile geometrik bozukluklar, parça miktarlarının küçük olması, kişilerin tarım arazilerinin dağınıklığının giderilmesi, daha verimli tarım arazilerinin sağlanması amaçlanmaktadır. Toplulaştırma çalışmaları ile aynı zamanda sosyal donatılar kazandırılmakta, ulaşım imkânları sağlanmakta, sulama imkânı olmayan tarım arazilerinin de sulamadan istifade ettirilmesi de sağlanmaktadır.

\section{Öneriler}

- Ülkemizde kadastro çalışmalarında çalışmaların yapıldığı dönemlerde meri olan mevzuatına göre parseller üretilmiştir. Tarım arazileri mevcut halleri ile sınırlandırılmış ve haritaya bağlanarak mülkiyet durumları tescil edilmiştir. Günümüzde toplulaştırma ile dahi yeter arazi büyüklüklerine ulaşmak mevcut parsel ve mülkiyet koşullarında mümkün görünmemektedir.

- Tarımda tam verimli bir üretim ve gelirin sağlanmasının modern tarım araç, gereçleri ve modern tarım teknikleri ile yapılması artık bir zorunluluk olarak görünmektedir. Tarımda kullanılan tüm teçhizatın 
verimli olması belirli bir büyüklükte tarım arazisinin işlenmesine bağl1dir.

- Projenin yer aldığı bölgenin topoğrafyası göz ardı edilerek; proje dâhilinde çalışma eki olarak sunulan Ek.3 haritada yer alan ada bazındaki taşınmazları bölünmeksizin birer tarla olarak bırakılması verimli tarım yapmak açısından tarımsal arazi büyüklükleri olarak uygun olacaktır. Bu durum işletme maliyetlerinden büyük tasarruf sağlanacağ1 gibi ürün planlanması ve modern tarım yöntemlerinin uygulanması açısından daha faydalı olacaktır. Ada bazında oluşacak bu taşınmazlara müştereken malik olacakların bu arazilerdeki tarımsal faaliyetleri müşterek oluşturacakları bir işletme ile yapmaları hem emek hem de maliyet tasarrufu sağlayacaktır. Bu işletmelerin kurulması, yönetilmesi, oluşacak olan artı değerlerin paylaştırılması konusunda ya da tüm bu arazilerin müşterek işletilmesini sağlayacak kurumsal bir yapının oluşturulması için gerekli yasal alt yapının ve mevzuat değişikliğinin yapılmasıyla bunun mümkün olabileceği değerlendirilmektedir. Konu hakkında yapılan bazı çalışmalarında bu önerileri destekler nitelikte sonuçlara ulaşıldığı görülmektedir (Akdeniz ve Temizel, 2018, s.160; Boyraz ve Üstüntaş, 2008, s.577; Duru, Gül ve Hayran, 2017, s.268). 


\section{$\underline{\text { Extended Abstract }}$}

\section{Land consolidation within the Scope of Land Reform: Evaluation of an Application in Balıkesir-Gönen District}

\author{
Kemal Y1ldiz \\ ORCID: 0000-0001-6685-3805
}

\author{
Halil İhsan Karalar \\ ORCID: 0000-0003-3147-4105
}

Issues related to agriculture have been on the agenda of humanity since the early ages when regular agriculture was introduced. The fact that the world population is constantly increasing and the amount of land available for agriculture is decreasing has made it necessary to protect the existing areas. Only protecting these areas is not enough. Since the use of the land where agricultural activities are carried out is directly related to productivity, it has been inevitable to carry out continuous reforms in this area.

Areas that can be cultivated in Turkey is limited. These, too, have been divided into multiple pieces due to reasons such as inheritance and share sales. Although the number of owners in the areas where agricultural activities are carried out is approximately 40 million, it is seen that only 75 per thousand of them are engaged in active agriculture and production. Farm size in Turkey, is insufficient to make efficient agriculture; Enterprises sizes are twice in European Union and three times in the United States. One of the biggest obstacles to the proliferation and development of agricultural enterprises is that the lands have a small and multi-part structure. The aforementioned justifications render it necessary to make consolidation regulations, one of the most important land reforms.

Land consolidation has begun studies in Turkey in the 1960s. It continues today. With consolidation studies, problems such as bringing together the scattered immovables of the owners in the areas where the application is carried out, providing transportation and irrigation facilities and eliminating geometric disorders are tried to be solved. However, it is considered that it 
will be possible to create consolidated immovables in the land sufficient sizes determined in the laws by making the legal infrastructure and legislative changes.

In the study, historical development related to land reform and consolidation has been discussed first. Land reform is the legal regulations that have to be made regarding the land, and the ability to make agriculture in large lands by combining small pieces of land. In detail, land reform are explained: Conservation and development of the soil, classification of agricultural lands, determination of minimum agricultural land and agricultural land with sufficient income and prevention of division, determining the procedures and principles that will ensure the planned use of agricultural land and sufficient income agricultural land in accordance with the environmental priority sustainable development principle, by classifying them in accordance with the principles, determining the minimum size of agricultural land and agricultural land with sufficient income and preventing their division, preparing land use plans, evaluating the social, economic and environmental dimensions in the process of conservation and development with participatory methods, preventing misuse and misuse, creating methods to ensure protection the procedures and principles regarding duties, powers and responsibilities.

The first land reform practices are based on the 1000s before Christ. It is possible to encounter regulations regarding land reform in almost all societies since then. In Turkey, there are regulations that started from the last period of the Ottoman Empire and have not reached a certain perfection today. The issue of land consolidation remains the most important and problematic issue in land reform. Although the social and economic benefits of land consolidation are clear, the application is not at the desired level of efficiency and effectiveness.

After that, a sample consolidation study on Balıkesir-Gönen District was analyzed. In the analysis, old-new overlapping property maps are examined. In the consolidation projects implemented, it is seen that land plots with agricultural bentness in accordance with the land quantity norms determined by the law no 5403. It is understood from the examination of the map that there are indeed lots of plots of land that do not have access and irrigation facilities, and the number of geometrically shaped parts is almost absent. It is certain that there is a structure in this area that requires consolidation work. However, one thing that draws our attention in this map is that the areas of some parcels in some blocks are kept very small. At the boundary of a few projects, 
it is seen that areas with smooth geometric shapes are formed, except for small areas that are formed due to the intersection points of roads and irrigation channels. In general terms, it is seen that the sample rural neighborhood consolidation project is an application suitable for consolidation purposes.

The subject was also discussed through an interview in the sample neighborhood. As a result of the interview; The greater use of agricultural land in Turkey is important in economic terms, but the legacy of the excess of the legal and manufacturing costs are obstacles to the development of agricultural production, multipart as a serious challenge to agricultural production, this very fragmented land structure of cooperatives, can be processed as a whole by associations and foundations, the main factor of the fragmented land structure is the inheritance law and it is a big problem that the inheritors do not choose the means of agreement for production, adopting the principle of single owner ownership in agricultural lands and ensuring that the transfer of immovables is directly understood and transferred to a party that will deal with agriculture and if necessary, legal regulations the necessary laws are not sufficient for consolidation and efficient operation of agricultural lands, and laws that will lead landowners to consolidate and agricultural production in the form of necessity are important. If it is aimed at the solution of the problem; In order to eliminate the problems, it is essential to update the inheritance law and enact an Agriculture Law that prioritizes production. The proposals to prioritize consolidation by various mechanisms and to restructure the sharing of heritage with regulations so as not to reduce agricultural production have come to the fore.

\section{Kaynakça/References}

Akdeniz, M. ve Temizel, K.E. (2018). Arazi toplulaştırma projelerinde başarının değişik göstergelere göre değerlendirilmesi. Anadolu Tarm Birliği Dergisi, 33, 149-161.

Alpat, S. (1975). Türkiye'de tarım reformunun sosyal yönü. Sosyal Siyaset Konferansları Dergisi, 26, 1-28.

Arazi Toplulaştırma Uygulama Yönetmeliği. (2017, 9 Aralık). Resmi Gazete (Sayı 30265).

Erişim Adresi: https://www.resmigazete.gov.tr/eskiler/2017/12/20171209-2.htm

Arazi Toplulaştırması ve Tarla İçi Geliştirme Hizmetleri Uygulama Yönetmeliği. (2019, 7 SSubat). Resmi Gazete (Sayl 30679). https://www.resmigazete.gov.tr/eskiler/2019/02/20190207-5.htm

Bakanlar Kurulu Kararı-2008/14338 Sayılı Kararname. (2008, 4 Aralı). Resmi Gazete (Sayı 27074). https://www.resmigazete.gov.tr/eskiler/2008/12/20081204-5.htm

Berki, Ş. (1970). Türkiye Cumhuriyeti Anayasasının toprak davası ile ilgili esasları. Ankara Üniversitesi Hukuk Fakültesi Dergisi, 27(1), 77-91. 
Boyraz, Z. ve Üstüntaş, Ö. (2008). Kırsal alanlarda arazi toplulaştırma çalışmalarının önemi. e-Journal of New World Sciences Academy, 3(3), 563-578.

Çamurcuoğlu, G. (2009). Türkiye Cumhuriyeti'nin toprak reformu ve milli burjuvazi yaratma çabası. Gazi Üniversitesi Hukuk Fakültesi Dergisi, 13(1-2), 161-178.

Demirtaş, E., Sarı, M., Sönmez, N. K. ve Altunbaş, S. (2016). Arazi toplulaştırmasında kullanılan toprak derecelendirme çalışmalarına yeni bir yaklaşım. DERIM, 20(1), 19-26.

Duru, S., Gül, A. ve Hayran, S. (2017). Türkiye'de arazi toplulaştırması: Mevzuat ve uygulamalar. Tarm Ekonomisi Dergisi, 23(2), 263-269.

Elias, H.T. (1998). History of land reform. Erişim adresi: https://www.britannica.com/topic/land-reform//History-of-land-reform

Güdül, A. (2017). 1861 Rus toprak reformu ve etkileri. Kırklareli Üniversitesi Sosyal Bilimler Dergisi, 1, 1-12.

Güneş, H.H. ve Sarı T. (2005). Türkiye'de tarım topraklarının mülkiyet yapısı ve tarihsel süreçteki değişimde Diyarbakır Örneği. Elektronik Sosyal Bilimler Dergisi, 4(13), 71-87.

İnci, İ. (2010). Atatürk Dönemi Türkiye'sinde toprak mülkiyet dağılımı ile ilgili bazı düzenlemeler. Atatürk Üniversitesi Türkiyat Araştırmaları Enstitüsü Dergisi (TEAD), 44, 345-359.

Kaya, S.Y. (2015). İskân ve toprak dağıtımı politikaları 1şığında çiftçiyi topraklandırma kanunu. Journal of Life Ekonomics Dergisi, 2(3), 77-105.

Kenanoğlu, M.M. (2006). 1858 arazi kanunnamesi ve uygulaması. Türk Hukuk Tarihi Araştırmalan Dergisi, 1, 107-138.

Kılıç, R. ve Demirbilek, M. (2011). Mülkiyet kavramının tarihsel gelişimi sürecinde ortaçağ ve reform hareketi. Dumlupınar Üniversitesi Sosyal Bilimler Dergisi, 30, 181190.

Korkut, S. (1984). Toprak reformu ve Türkiye. Ankara: TBMM Basımevi.

Küsek, G. (2014). Türkiye'de arazi toplulaştırmasının yasal durumu ve tarihsel gelişimi. Çukurova Üniversitesi Ziraat Fakültesi (Ç.Ü.Z.F) Dergisi, 29(1), 1-6.

Milli Eğitim Bakanlı̆̆ $\quad$ (2019). Köy enstitüleri. http://www.meb.gov.tr/meb/hasanali/egitimekatkilari/koy_enstitu.htm.

Önal, N.E. (2010). Türkiye'nin iktisadi ve siyasi tarihinde toprak reformu tartışmalarınin rolü. MEMLEKET Siyaset Yönetim Dergisi, 5(12), 6-20.

Özçelik, Ş.B. (2015). 5403 Sayılı Toprak Koruma ve Arazi Kullanımı Kanunu'nda 6537 Sayılı Kanun'la yapılan değişiklikler ve değerlendirilmesi, Gazi Üniversitesi Hukuk Fakültesi Dergisi, XIX(1), 87-110.

Özer, A. (2010). Çanakkale İli Biga İlçesi Yeniçiflik Köyü arazi toplulaştırması sonrası durumun izlenmesi ve değerlendirilmesi.Yayımlanmamış yüksek lisans tezi. Çanakkale Üniversitesi, Fen Bilimleri Enstitüsü, Tarımsal Yapılar ve Sulama Ana Bilim Dalı, Çanakkale.

Pamak, M. (2011). Türkiye'de toprak reformu. Sosyoloji Konferansları, 18, 127-162. 
Tekelioğlu, Y. (2010). Toprak reformu ve Türkiye uygulamaları. Akdeniz Üniversitesi I.I.̇.F. Dergisi, 10(19), 43-80.

Toklu, N. (2010). Türkiye'de toprak reformu politikalarının değerlendirilmesi. Yayımlanmamış yüksek lisans tezi. Selçuk Üniversitesi, Fen Bilimleri Enstitüsü, Konya.

Tarım Reformu Genel Müdürlüğü, (2010). Tarm Reformu Genel Müdürlü̈̆̈̈̈ 2009 yılı faaliyet sonuçları raporu, Ankara.

Türker, M. (2010). Dünya'da ve ülkemizde toprak ve tarım reformu uygulamaları. Üçüncü Sektör Kooperatif̧cilik Dergisi, 45(3), 38-57.

Türkiye İstatistik Kurumu (2019). Tarımsal İşletme Yapı İstatistikleri, Erişim adresi: http://www.tuik.gov.tr/PreTablo.do?alt_id=1003.

5403 Sayılı Toprak Koruma ve Arazi Kullanımı Kanunu. (2005, 19 Temmuz), Resmi Gazete (Say1 25880). https://www.resmigazete.gov.tr/eskiler/2005/07/200507192.htm

5578 Sayılı Toprak Koruma ve Arazi Kullanımı Kanununda Değişiklik Yapılması Hakkında Kanun. (2007, 9 Şubat). Resmi Gazete (Sayı: 26429). https:/www.resmigazete.gov.tr/eskiler/2007/02/20070209-1.htm

6537 Sayılı Toprak Koruma ve Arazi Kullanımı Kanununda Değişiklik Yapılması Hakkında Kanun. (2014, 15 Mayı). Resmi Gazete (Say1 29001). https://www.resmigazete.gov.tr/eskiler/2014/05/20140515-1.htm 


\section{Ekler}

Ek.1. : Örnek Kırsal Mahalle Toplulaştırma Projesi Alanı Eski Mülkiyet Durumu Haritas1

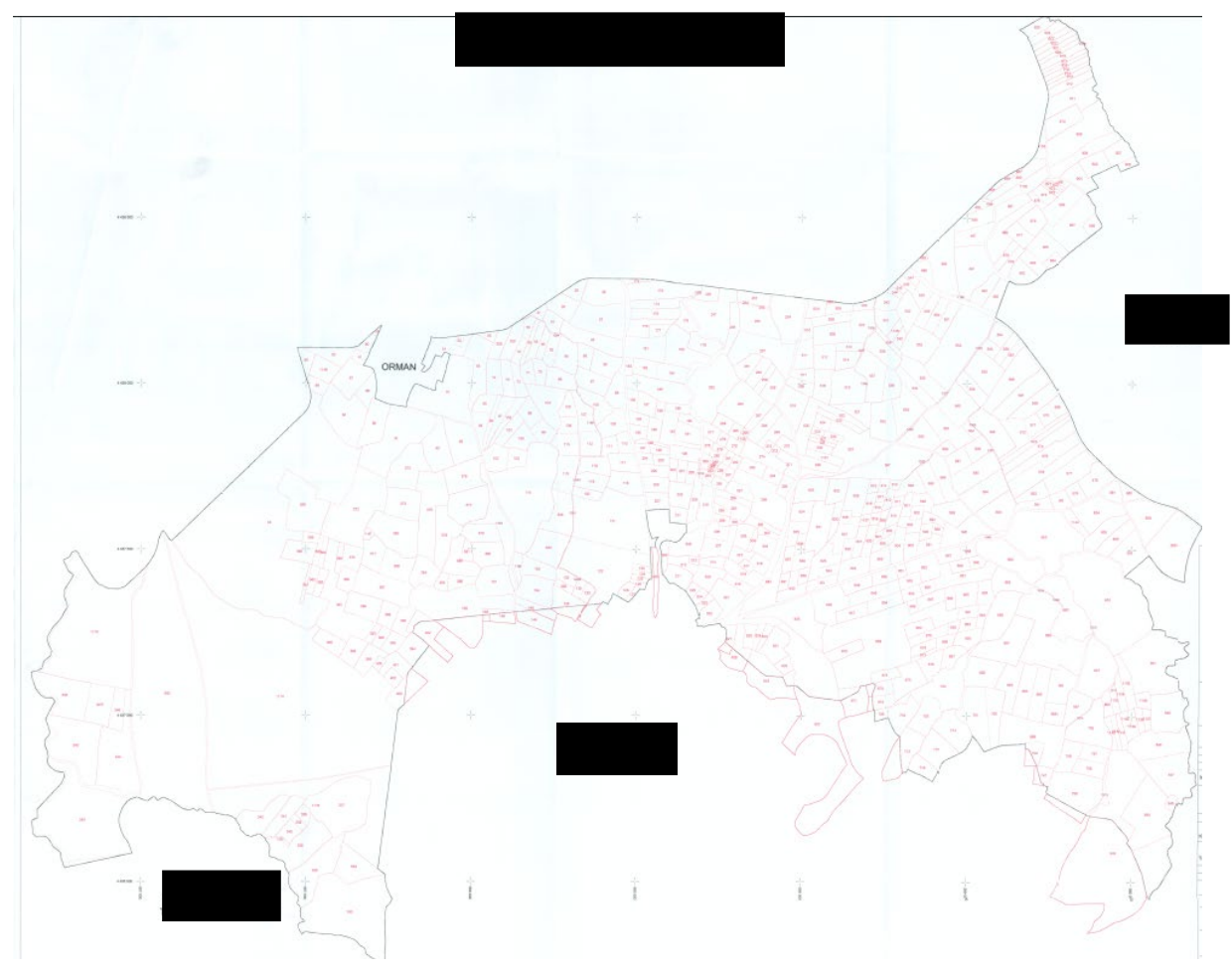


Ek.2. : Örnek Kırsal Mahalle Toplulaştırma Projesi Alanı Ada (Blok) Bölüm Haritası

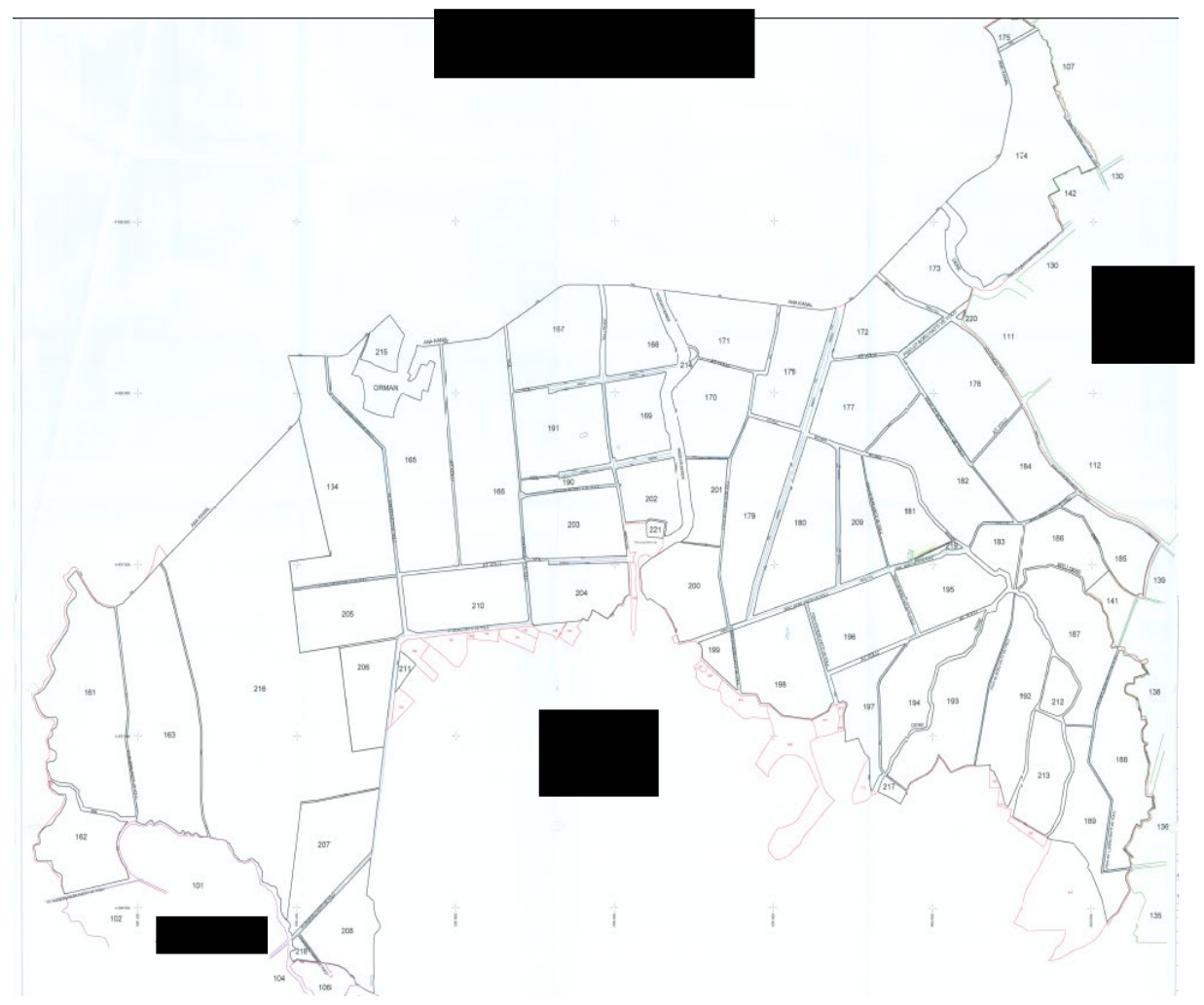


Ek.3. : Örnek Kırsal Mahalle Toplulaştırma Projesi Alanı Eski-Yeni Çakışık Mülkiyet Durumu Haritası

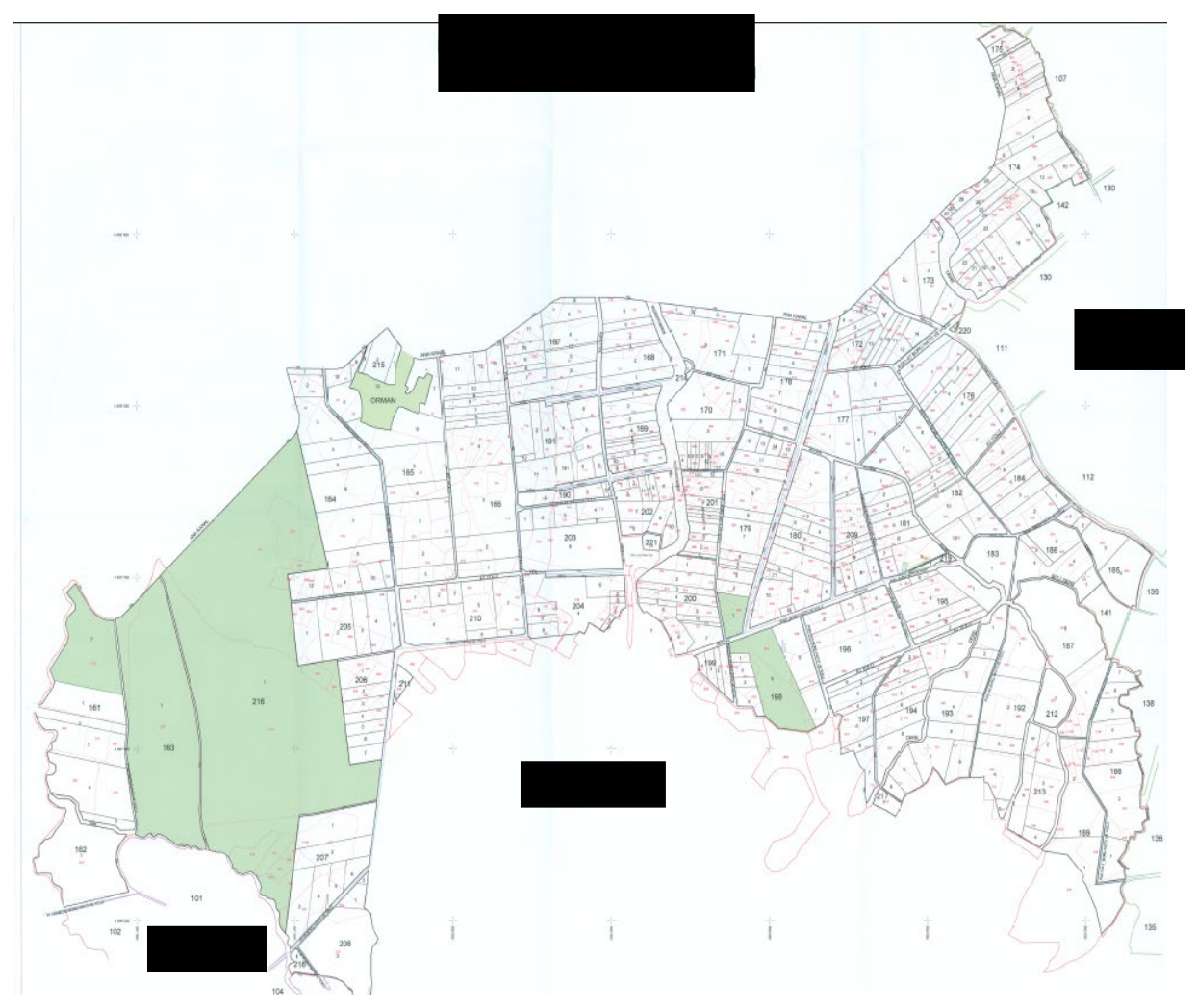

